\title{
Carbonyl Reductase [NADPH] 3
}

National Cancer Institute

\section{Source}

National Cancer Institute. Carbonyl Reductase [NADPH73. NCI Thesaurus. Code C103989.

Carbonyl reductase [NADPH] 3 (277 aa, $31 \mathrm{kDa}$ ) is encoded by the human CBR3 gene.

This protein plays a role in the reduction of metabolically active carbonyl compounds. 